УДК 662.76

\title{
ДОСЛІДЖЕННЯ ШВИДКОГО ПІРОЛІЗУ БІОМАСИ В АБЛЯЦІЙНОМУ ШНЕКОВОМУ РЕАКТОРІ
}

\author{
Клименко В.М. ${ }^{1}$, чл.-кор. НАН України, Баштовий А.І. ${ }^{1}$, канд. техн. наук, Зубенко В.І. ${ }^{\text {, }}$ \\ Антощук T.O. ${ }^{2}$ \\ 'Iнститут технічної теплофізики НАН Украӥни, вул. Желябова, 2а, Київ, 03680, Украӥна \\ ${ }^{2}$ НТЦ “Біомаса”, вул. Желябова, 2а, Київ, 03067, Україна
}

Представлено результати експериментальних досліджень процесу швидкого піролізу біомаси 3 метою отримання біонафти, вуглецевого залишку та піролізного газу в абляційному реакторі шнекового типу. Запропоновано та реалізовано заходи щодо вдосконалення технології піролізу. Проведено порівняльний аналіз даних експерименту $з$ даними іноземних авторів.
Представлено результаты экспериментальных исследований процесса быстрого пиролиза биомассы с целью получения бионефти, углеродистого остатка и пиролизного газа в абляционном реакторе шнекового типа. Проведен их сравнительный анализ с иностранными аналогами. Предложены мероприятия по дальнейшему усовершенствованию данной технологии.
The paper presents results of experimental investigations of fast pyrolysis of biomass in the ablative screw reactor to obtain bio-oil, carbonaceous residue and pyrolysis gas. Their comparative analysis with foreign similar experimental data was carried out. The measures to further development of this technology were suggested.

Бібл. 9, рис. 1, табл. 4.

3 інформаційних джерел та оцінок Міжнародного енергетичного агентства (MEA) [1] відомо, що рідке біопаливо $\epsilon$ одним 3 перспективних видів органічного рідкого альтернативного палива. Рідке біопаливо можна отримати 3 альтернативних видів палива, а саме 3 біомаси, шляхом термічної переробки, процесом піролізу [2-3].

Відповідно до оцінок MEA, а також до стандартів виробництва рідкого біопалива, не кожний вид процесу піролізу може відповідати екологічним критеріям виробництва. Також слід зазначити, що піроліз спрямований не лише на отримання рідкого біопалива (біонафти), а й на виробництво піролізного газу. У випадку застосування досконаліших технологій, у технологічному процесі можна отримувати якісний вуглецевий залишок, який може бути використаний для виробництва твердого біопалива.

Мета даного дослідження полягає в удосконаленні роботи експериментальної установки швидкого абляційного піролізу біомаси, розробленої в ІТТФ НАНУ та порівнянні даних експерименту із даними іноземних авторів [4,5].

У роботі [6] були представлені результати експериментів на установці швидкого піролізу. Представлена установка мала ряд конструктивних недоліків, а характеристики отриманих продуктів піролізу мали досить низькі показники. Щоб подолати виявлені недоліки, попередня конструкція установки була модифікована (рис. 1). Основна модифікація полягала у зміні конструкції абляційного реактора 3 метою забезпечення необхідного температурного режиму окремо для різних зон реактора:

1) зона нагріву часток біомаси до необхідної температури;

2) зона проведення піролізного процесу;

3) зона видалення продуктів піролізної реакції.

Проведені експерименти показали, що завдяки визначенню оптимальних умов роботи лабораторної установки вдалося досягти тривалості стабільної роботи установки на рівні 180 хв. та постійного виходу біонафти на рівні до $50 \%$ мас. 


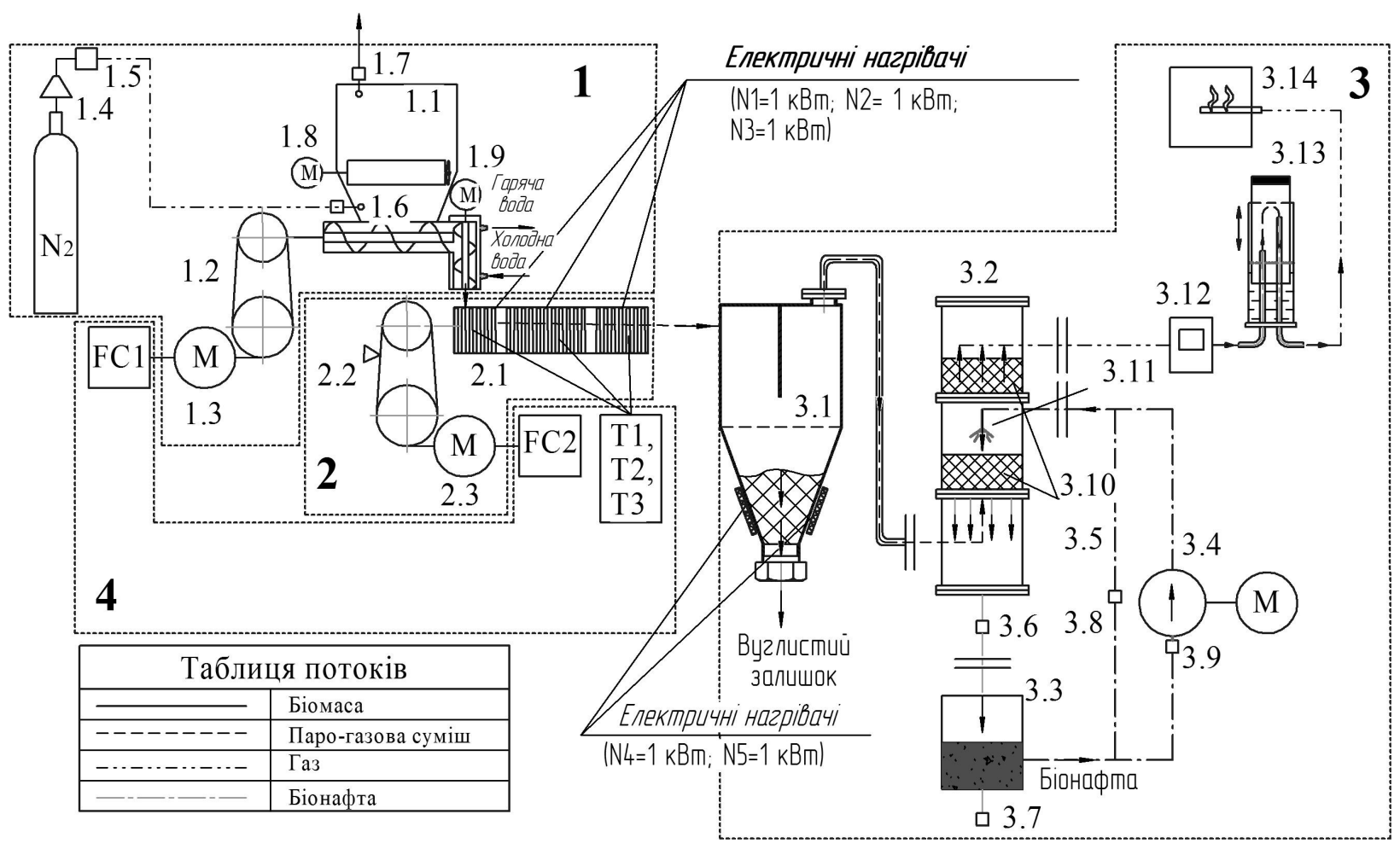

Рис. 1. Технологічна схема лабораторної установки швидкого піролізу біомаси: 1 - система подачі сировини, 1.1 - шнековий жсивильник сировини з бункером; 1.2 - клиноремінна передача приводу шнеку живильника, 1.3 - двигун-редуктор, 1.4 - газовий редуктор, 1.5 - регулятор витрати газу, 1.6, 1.7-крани; 1.8 - двигун-редуктор приводу мішалки бункера; 1.9 - двигун-редуктор приводу шнека вертикального патрубка; 2 -реакторний блок, 2.1 -реактор зі шнеком,

2.2 - клиноремінна передача приводу шнеку реактора, 2.3 - електродвигун;

3 - система парогазоочистки та утилізації піролізних газів, 3.1 - осаджувальна камера, 3.2 - скрубер, 3.3 - бак для збору біонафти, 3.4 -насос,

3.5 - байпас (для регулювання швидкості подачі охолоджувальної рідини насосом), 3.6 - 3.9-вентилі запірні, 3.10 - кільця Рашига; 3.11 - форсунка;

3.12 - лічильник витрат піролізного газу, 3.13 - газгольдер,

3.14 - пальник для спалювання піролізного газу; 4 -блок жсивення та керування.

Аналіз [5, 7, 8] показав, що конструкції абляційних реакторів швидкого піролізу для лабораторних досліджень досить подібні, а основні відмінності полягають у загальному виконанні та автоматизації даних установок, а також у використанні приладів, що вимірюють основні показники та параметри їх роботи.

Принципову схему експериментальної установки, розробленої в ІТТФ НАНУ, представлено на рис. 1. На зовнішній поверхні реактора розташовані три електричні нагрівачі потужністю 1 кВт кожен. Управління нагрівачами реактора здійснюється за сигналом термопар, що закріплені на зовнішній поверхні корпусу реактора за допомогою мікропроцесорного регулятора температури. Максимальна температура реактора, яку може забезпечити нагрівач, становить $650{ }^{\circ} \mathrm{C}$. Для запобігання втрат тепла у навколишнє середовище корпус реактора покрито теплоізоляційними матеріалами.

Шнек реактора приводиться в дію за допомогою електродвигуна змінного струму та ре- 
дуктора. Частота обертання електродвигуна регулюється струмом частотою від 10 до 57,5 Гц за допомогою силового перетворювача частоти, що дозволяє змінювати швидкість переміщення часток біомаси відносно корпусу реактора.

Вихід реактора з'єднано напряму з осаджувальною камерою без проміжних трубопроводів для забезпечення вільного виходу продуктів піролізу. Осаджувальна камера оснащена перегородкою, яку огинають продукти піролізу, та патрубком для видалення твердих фракцій вуглецевого залишку. На зовнішній поверхні бокових стінок осаджувальної камери встановлено два охоронні електричні нагрівачі потужністю 1 кВт кожен, які дозволяють підтримувати температуру цих елементів установки на рівні до $400{ }^{\circ} \mathrm{C}$ та запобігати передчасній конденсації біонафти через різкий перепад температур між зонами. Управління охоронними нагрівачами здійснюється за сигналами термопар, які закріплені на стінках осаджувальної камери за допомогою мікропроцесорних регуляторів температури.

Газовий тракт установки включає систему подачі азоту та систему трубопроводів, що з'єднують скрубер з пальником, що призначений для спалювання піролізного газу.

В якості сировини використовувалась різні зразки деревної тирси вологістю $4 \%$ мас. 3 розмірами часток $0,5 \ldots 0,7 \mathrm{Mм}, 0,5 \ldots 1,0$ мм та 0,5..5 мм та насипною щільністю відповідно

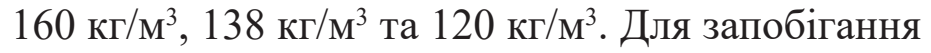
зависання сировини, бункер та вертикальний патрубок живильника обладнані відповідно мішалкою та шнеком, що приводяться в дію двигунами-редукторами.

Порядок проведення експериментів наступний. Зразки подрібненої біомаси масою 3...3,5 кг завантажували у бункер, який герметично закривали для уникнення витоку піролізних газів у зворотньому напрямку та запобігання загазованості лабораторного приміщення. Перед початком експерименту у нижній патрубок бункеру протягом 20..25 хвилин подавали азот 3 постійною витратою 0,117 м³/год для продувки бункера та тракту від реактора до скрубера системи конденсації біонафти. Повітря з бункера витісняли азотом та виводили через верхній патрубок та пальник у навколишнє середовище. Після цього відміряли дизельне пальне (3 л) та заливали у накопичувальний бак.

Після завантаження палива в бункер, герметизації установки та продувки іiі азотом вмикали електричні нагрівачі реактора, а також осаджувальної камери і розігрівали елементи установки до робочих температур, необхідних у даному експерименті. Регулювання температури реактора здійснювали по сигналах термопар, вмонтованих у зовнішню стінку реактора, 3 урахуванням перепадів температур між зовнішньою та внутрішньою стінками залежно від розрахункової продуктивності установки. Встановлене на регуляторі значення температури дорівнювало сумі необхідної температури сировини в реакторі та розрахункового перепаду температур по товщині стінки реактора. В експериментах температуру зовнішньої стінки реактора підтримували на рівні $550 \ldots 650{ }^{\circ} \mathrm{C}$, температуру осаджувальної камери на рівні $50{ }^{\circ} \mathrm{C}$. Одночасно вмикали систему вимірювання та реєстрації температур, яка включає багатоканальний вимірювальний прилад та персональний комп'ютер.

Циркуляційний насос вмикали після виходу установки на необхідний температурний режим для подачі дизельного пального на зрошення скрубера.

Для забезпечення стабільної роботи системи живлення сировиною вмикали приводи мішалки бункеру та шнека вертикального патрубка живильника. У щиті управління на перетворювачах частот, що живлять електричні двигуни приводу шнека реактора та шнека подачі палива, встановлювали частоти струму, що відповідають заданій швидкості обертання відповідних шнеків.

Умови проведення експериментів та отримані результати представлено у табл. 1, 2 .

Як видно з результатів експерименту, горючі гази складають близько 80 \% від об'єму усіх піролізних газів, отриманих в експерименті. Завдяки значному вмісту $\mathrm{CO}_{2}, \mathrm{H}_{2}, \mathrm{CH}_{4}$, що складає більше 50 \% від об'єму, калорійність піролізного газу $є$ досить високою. Він може бути використаний, наприклад, для організації нагріву реактора замість використання 
електроенергії.

У табл. 3 приведено порівняння характеристик біонафти, отриманої на експериментальній установці ІТТФ та в Університеті Флоренції [5].
Виходячи з результатів можна зробити висновок, що отримана біонафта не поступається за основними характеристиками біонафті, отриманої іноземними авторами.

Табл. 1. Умови та результати експериментальних досліджень абляційного піролізу біомаси на лабораторній установці

\begin{tabular}{|c|c|c|c|c|c|c|}
\hline \multirow{2}{*}{ Показники } & \multirow{2}{*}{$\begin{array}{c}\text { Розмір- } \\
\text { ність }\end{array}$} & \multicolumn{5}{|c|}{ Номер експерименту } \\
\hline & & №1 & №2 & №3 & №4 & №5 \\
\hline $\begin{array}{l}\text { Температура зовнішньої } \\
\text { поверхні стінки реактора }\end{array}$ & ${ }^{\circ} \mathrm{C}$ & 550 & 600 & 550 & 550 & 650 \\
\hline $\begin{array}{l}\text { Температура } \\
\text { осаджувальної камери }\end{array}$ & ${ }^{\circ} \mathrm{C}$ & \multicolumn{5}{|c|}{50} \\
\hline Витрата азоту для продувки & $\mathrm{M}^{3} /$ год & \multicolumn{5}{|c|}{0,117} \\
\hline $\begin{array}{l}\text { Швидкість руху часток } \\
\text { сировини в реакторі }\end{array}$ & $\mathrm{M} / \mathrm{c}$ & \multicolumn{5}{|c|}{1,0} \\
\hline $\begin{array}{l}\text { Розмір частинок } \\
\text { сировини }\end{array}$ & мM & $0,5 \ldots 1$ & $0,5 \ldots 1$ & $0,5 \ldots 0,7$ & $0,5 \ldots 5$ & $0,5 \ldots 5$ \\
\hline $\begin{array}{l}\text { Час перебування частинок } \\
\text { біомаси в реакторі }\end{array}$ & $\mathrm{c}$ & \multicolumn{5}{|c|}{1,0} \\
\hline Вологість сировини & $\%$ & \multicolumn{5}{|c|}{4} \\
\hline Час експерименту & хв. & 180 & 130 & 45 & 120 & 180 \\
\hline $\begin{array}{l}\text { Температура } \\
\text { охолоджувальної рідини }\end{array}$ & ${ }^{\circ} \mathrm{C}$ & 12 & 14 & 10 & 12 & 13 \\
\hline $\begin{array}{l}\text { Витрата } \\
\text { охолоджувальної рідини }\end{array}$ & $\mathrm{M}^{3} /$ год & \multicolumn{5}{|c|}{0,18} \\
\hline Маса переробленої біомаси & кг & 2,88 & 2,57 & 3,49 & 2,68 & 3,13 \\
\hline Маса вуглецевого залишку & кг & 0,7 & 0,432 & 1,47 & 0,998 & 0,78 \\
\hline Вихід вуглецевого залишку & \% мас. & 24,3 & 16,8 & 42 & 37 & 24,9 \\
\hline Маса біонафти & кг & 1,408 & 1,262 & 1,38 & 1,18 & 1,21 \\
\hline Вихід біонафти & \% мас. & 48,9 & 49,1 & 39 & 44 & 38,6 \\
\hline Густина біонафти & $\kappa \Gamma / \mathrm{M}^{3}$ & 1110 & 1190 & 1140 & 1020 & 1105 \\
\hline $\begin{array}{l}\text { Вища теплота згорання } \\
\text { біонафти }\end{array}$ & МДж/кг & $\begin{array}{c}\text { не визна- } \\
\text { чалася } \\
\end{array}$ & 13,77 & \multicolumn{3}{|c|}{ не визначалася } \\
\hline $\begin{array}{l}\text { Вихід газів та втрати } \\
\text { (по балансу) }\end{array}$ & $\%$ мac. & 26,8 & 34,1 & 18 & 19 & 36,5 \\
\hline $\begin{array}{l}\text { Продуктивність установки } \\
\text { по біомасовій сировині }\end{array}$ & кг/год & 0,96 & 1,186 & 4,65 & 1,338 & 1,044 \\
\hline
\end{tabular}

Табл. 2. Компонентний склад піролізного газу з експерименту № 2

\begin{tabular}{|c|c|c|c|c|c|c|c|c|c|c|c|c|c|}
\hline $\begin{array}{c}\text { Компо- } \\
\text { нент }\end{array}$ & $\mathrm{H}_{2}$ & $\mathrm{CO}$ & $\mathrm{CH}_{4}$ & $\mathrm{CO}_{2}$ & $\mathrm{C}_{2} \mathrm{H}_{4}$ & $\mathrm{C}_{2} \mathrm{H}_{6}$ & $\mathrm{C}_{3} \mathrm{H}_{6}$ & $\mathrm{C}_{3} \mathrm{H}_{8}$ & $\mathrm{iC}_{4} \mathrm{H}_{10}$ & $\mathrm{H}_{2} \mathrm{O}$ & $\mathrm{N}_{2}$ & Сума & $\mathrm{Q}_{\text {н }}^{\mathrm{p}}$ \\
\hline $\begin{array}{c}\text { \% від } \\
\text { об'єму }\end{array}$ & 9,51 & 34,03 & 11,65 & 24,35 & 1,43 & 1,38 & 0,19 & 0,71 & 0,55 & 1,72 & 14,19 & 100 & $\begin{array}{c}12,67 \\
\text { МДж/ }\end{array}$ \\
\hline
\end{tabular}


Табл. 3. Властивості біонафти установки ІТТФ та Університету Флоренції

\begin{tabular}{|l|c|c|c|}
\hline \multicolumn{1}{|c|}{ Назва показника } & $\begin{array}{c}\text { Одиниця } \\
\text { вимірювання }\end{array}$ & $\begin{array}{c}\text { Результати аналізу } \\
\text { ІТТФ }\end{array}$ & $\begin{array}{c}\text { Результати аналізу } \\
\text { Університету Флоренції }\end{array}$ \\
\hline Масова частка вологи & $\%$ & 47,2 & $20 \ldots 30$ \\
\hline Масова частка сірки & $\%$ & 0,028 & $0,02 \ldots 0,05$ \\
\hline Вища теплота згорання & МДж/кг & 16,01 & $16,6 \ldots 19,4$ \\
\hline $\begin{array}{l}\text { Теплота згорання нижча в } \\
\text { перерахунку на робоче паливо }\end{array}$ & МДж/кг & 13,77 & $13 \ldots 18$ \\
\hline
\end{tabular}

Як видно масова частка вологи складає 47,2 \%, що у порівняні з даними Університету Флоренції є досить великим показником. У літературних та наукових джерелах [7, 9] зустрічаються дані, що в лабораторних установках вихід піролізної рідини із сухої низькозольної біомаси може складати до $65 \%$ за вагою. Але навіть при використанні сухої біомаси вода завжди утворюється внаслідок процесу піролізу 3 компонентів палива, a загальний вихід рідких продуктів 3 сухої біомаси може досягати 75 \%. Природна вологість сировини впливає на вміст $\mathrm{H}_{2} \mathrm{O}$ у біонафті. У випадках, коли вологість дуже висока (понад $30 \%$ б) біонафта розділяється на дві фази, що мають різні властивості $[5,6,9]$.

Вуглецевий залишок після кожного експерименту збирався для проведення відповідних аналізів, результати яких представлені у табл. 4.

Табл. 4. Характеристики вуглецевого залишку для експерименту №2

\begin{tabular}{|c|c|c|c|}
\hline Показники & Розмірність & Величина & $\begin{array}{c}\text { Нормативний документ } \\
\text { на метод випробувань }\end{array}$ \\
\hline $\begin{array}{l}\text { Загальна волога аналітичного } \\
\text { зразка при робочому стані палива }\end{array}$ & $\%$ & 3,8 & ГОСТ 27314 \\
\hline $\begin{array}{l}\text { Зольність } \\
\text { - на робочий стан палива, } \\
\text { - на сухий стан палива }\end{array}$ & $\%$ & $\begin{array}{l}3,1 \\
3,2 \\
\end{array}$ & $\begin{array}{l}\text { ГОСТ } 11022 \\
\text { ГОСТ } 27313 \\
\end{array}$ \\
\hline $\begin{array}{l}\text { Вища теплота згорання } \\
\text { на сухий стан палива }\end{array}$ & МДж/кг & 30,4 & $\begin{array}{l}\text { ДСТУ ISO } \\
1928: 2006 \\
\end{array}$ \\
\hline $\begin{array}{c}\text { Нижча теплота згоряння } \\
\text { на робочий стан палива } \\
\end{array}$ & МДж/кг & 28,2 & $\begin{array}{l}\text { ДСТУ ISO } \\
1928: 2006\end{array}$ \\
\hline $\begin{array}{l}\text { Масова частка сірки } \\
\text { - на робочий стан палива; } \\
\text { - на сухий стан палива }\end{array}$ & $\%$ & $\begin{array}{c}\text { Менш ніж: } \\
0,016 \\
0,017\end{array}$ & $\begin{array}{l}\text { ДСТУ ISO } \\
1928: 2006\end{array}$ \\
\hline
\end{tabular}

Як видно з таблиці, вуглецевий залишок має дуже високу вищу теплоту згорання ( 30 МДж/ кг), тому його можна використовувати в якості палива для побутового застосування, а також для технологічних потреб промисловості. Існує багато різноманітних сфер застосування цьому продукту, наприклад, використання для виробництва брикетів 3 деревного вугілля, а також як палива безпосередньо або в суміші з кам'яним вугіллям.
Продукти згоряння вуглецевого залишку містять менше оксидів сірки та азоту, ніж продукти згоряння кам'яного вугілля. Вуглецевий залишок також може бути використаний для виробництва активованого вугілля [7].

Проведена серія експериментів показала, що конструкція шнеку потребує подальшої модернізації з метою ефективнішого проведення процесу піролізу деревної тирси. Цілком ймовір- 
но, що частка деревини повністю не розкладається при проходженні через реактор. При цьому час існування смоляних парів є достатньо високим та, як наслідок, вони зазнають впливу вторинних реакцій. Цим і пояснюється менша частка виходу біонафти та високий вміст вологи в ній, у порівнянні з іноземними аналогами.

Частки сировини проходять реактор з майже однаковою швидкістю. У першій зоні реактора частки розігріваються до необхідної температури для піролізного розкладання, у другій вони розкладаються на парогазову суміш та тверді частки вуглецевого залишку. Утворені продукти піролізу перебувають у даному стані більше часу, ніж необхідно для запобігання вторинних реакцій, перш ніж вони будуть видалені з реактору. Згідно показанням термопар, що розміщені на корпусі реактора, спостерігалось падіння температури на вході реактора під час надход ження свіжої сировини на $50 . .100^{\circ} \mathrm{C}$ у залежності відпродуктивності системиподачі сировини. Зона, в якій спостерігалось падіння температури, поширювалась майже на третину довжини реактору. Це дає змогу стверджувати, що біомаса, пройшовши $1 / 3$ довжини реактору, далі не відбирає тепло від корпусу реактора i, відтак, повністю розігрівається до необхідної для процесу піролізу температури, а може й перегрівається завдяки роботі транспортування в реакторі.

Враховуючи виявлені особливості проходження процесу абляційного процесу, подальші вдосконалення реактору полягають у оптимізації кроку витків шнеку, що призведе до збільшення швидкості проходження сировини через першу та третю зони реактора, а через другу зону - до іiі зменшення. Таким чином, зменшується час нагрівання сировини до необхідної температури, а продукти піролізу максимально швидко видаляються з реактору.

Результати робіт іноземних авторів [3, 5, 6, 9] та отримані результати експериментів дозволяють стверджувати, що для ефективного проведення процесу абляційного піролізу повинні виконуватися такі умови:

- висока щільність теплового потоку від нагрівача до зразку - до $5 \mathrm{MBT}^{-2} \mathrm{M}^{-2}$;

- ефективне видалення первинних продуктів піролізу з поверхні реактора для забезпечення часу перебування продуктів піролізу в парогазовому стані до $1 \mathrm{c}$;

- відсутність кисню у зоні реакції;

- швидкість переміщення часток у реакторі $1 \mathrm{M} / \mathrm{c}$.

\section{Висновки}

1. Модифіковано лабораторну установку, а саме організовано трьохзонний регульований нагрів реактору, систему подачі сировини обладнано додатковим шнеком вертикального патрубку та мішалкою бункеру, систему утилізації піролізних газів оснащено газгольдером та пальником для спалювання піролізного газу.

2. Проведено серію експериментів з піролізу подрібненої деревної біомаси (тирси) 3 отриманням біонафти. Отримана біонафта має властивості, що є типовими для рідини - продукту швидкого піролізу біомаси.

3. Визначено оптимальні режимні параметрами роботи пілотної піролізної установки 3 виходом біонафти близько 50 \% від маси переробленої сировини:

- температура корпусу реактора $-600{ }^{\circ} \mathrm{C}$,

- фракція часток сировини повинна бути в межах $0,5 \ldots 1$ мм,

- продуктивність системи подачі сировини 1,2 кг/год,

- швидкість руху часток сировини в реакторі $-1 \mathrm{M} / \mathrm{c}$.

\section{ЛІТЕРАТУРА}

1. Bridgwater A.V. The Status of Fast Pyrolysis of Biomass in Europe // Proc. of the 10th Europ. Bioenergy Conf., Wurzburg, Germany, 8-11 June, 1998, CARMEN, - 1998. - P. 268-271.

2. Lédé $J$. Biomass fast pyrolysis reactors: a review of a few scientific challenges and of recommended research topics // Oil Gas Sci. Technol.-Rev. IFP Energies Nov. 68 (5) - 2013.- P. 801-814.

3. Lédé J., Diebold J.P., Peacocke G.V.C., Piskorz J. The nature and properties of intermediate and unvaporized biomass pyrolysis materials, in: A.V. Bridgwater, et al. (Eds.) // Fast Pyrolysis of Biomass: A Handbook, CPL Press, Newburry (UK) 1999. 
4. Lede J., Panagopoulos J., Li H.Z. and Villermaux $J$. Fast pyrolysis of wood: direct measurement and study of ablation rate // Fuel, 1985. - Vol. 64, Issue 11. - P. 1514-1520.

5. Chiaramonti D., Oasmaa A., Solantausta $Y$. "Power generation using fast pyrolysis liquids from biomass" // Renewable and Sustainable Energy Reviews (http://www.sciencedirect.com), 2005.

6. Гелетуха Г.Г., Жовмір М.М., Желєзна Т.А., Зубенко B.I. Експериментальне дослідження швидкого піролізу біомаси в абляційному шнековому реакторі.// Промислова теплотехніка. 2013. - T.35, №1, С.87 - 92
7. Bridgwater A.V. Review of fast pyrolysis of biomass and product upgrading // Biomass Bioenergy 38 (2011), P. 1-27.

8. Lede J., Authier $O$. Temperature and heating rate of solid particles undergoing a thermal decomposition. Which criteria for characterizing fast pyrolysis? // Journal of Analytical and Applied Pyrolysis. - 2015. - Vol. 113, P. 1-14

9. Mettler M.S., Mushrif S.H., Paulsen A.D., Javadekar A.D., Vlachos D.G., Dauenhauer P.J. Revealing pyrolysis chemistry for biofuels production: conversion of cellulose to furans and small oxygenates, Energy Environ. Sci. 5 (2012), P.5414-5424. 


\section{RESEARCH OF BIOMASS FAST PYROLYSIS IN THE ABLATIVE SCREW REACTOR}

Klimenko V.M. ${ }^{1}$, Bashtovyi A.I. ${ }^{1}$, Zubenko V.I. ${ }^{1}$, Antoshchuk T.O. ${ }^{2}$

${ }^{1}$ Institute of Engineering Thermophysics of the National Academy of Sciences of Ukraine, str. Zhelyabova, 2a, Kyiv, 03680, Ukraine

${ }^{2}$ Scientific Engineering Centre "Biomass", str. Zhelyabova, 2a, Kyiv, 03067, Ukraine

In the article flowsheet of the laboratory pyrolysis installation with the screw type reactor and the explanation how it works are given. The results of the experiments of fast pyrolysis of biomass with the propose to obtain bio-oil, carbonaceous residue and pyrolysis gas in the ablative reactor were presented. The comparative analysis with foreign similar experimental data was carried out. The process of ablative pyrolysis of biomass was investigated and the measures to further improving of the technology were proposed. It was discovered that the effective ablative pyrolysis process should be carried out under the following condition: high heat flux, effective removal of the primary pyrolysis products from the reactor surface and the absence of oxygen in the reaction zone.

References 9, tables 4, figure 1 .

Key words: pyrolysis, biomass, bio-oil, pyrolysis gas, carbonaceous matter

1. Bridgwater A.V. The Status of Fast Pyrolysis of Biomass in Europe // Proc. of the 10th Europ. Bioenergy Conf., Wurzburg, Germany, 8-11 June, 1998, CARMEN, - 1998. - P. 268-271.

2. Lédé J. Biomass fast pyrolysis reactors: a review of a few scientific challenges and of recommended research topics // Oil Gas Sci. Technol.-Rev. IFP Energies Nov. 68 (5) - 2013.- P. 801-814.

3. Lédé J., Diebold J.P., Peacocke G.V.C., Piskorz J. The nature and properties of intermediate and unvaporized biomass pyrolysis materials, in: A.V. Bridgwater, et al. (Eds.) // Fast Pyrolysis of Biomass: A Handbook, CPL Press, Newburry (UK) 1999.

4. Lede J., Panagopoulos J., Li H.Z. and Villermaux J. Fast pyrolysis of wood: direct measurement and study of ablation rate // Fuel, 1985. - Vol. 64, Issue 11. - P. 1514-1520.

5. Chiaramonti D., Oasmaa A., Solantausta $Y$. "Power generation using fast pyrolysis liquids from biomass" // Renewable and Sustainable Energy Reviews (http://www.sciencedirect.com), 2005.

6. Geletukha G.G., Zhovmir M.M., Zheliezna T.A., Zubenko V.I. Experimental investigation of biomass fast pyrolysis in the ablative screw reactor // Promyshlennaya teplotekhnika . - 2013, v. 35, N 1, P. $87-92$.

7. Bridgwater A.V. Review of fast pyrolysis of biomass and product upgrading // Biomass Bioenergy 38 (2011), P. 1-27.

8. Lede J., Authier O. Temperature and heating rate of solid particles undergoing a thermal decomposition. Which criteria for characterizing fast pyrolysis? // Journal of Analytical and Applied Pyrolysis. - 2015. - Vol. 113, P. 1-14.

9. Mettler M.S., Mushrif S.H., Paulsen A.D., Javadekar A.D., Vlachos D.G., Dauenhauer P.J. Revealing pyrolysis chemistry for biofuels production: conversion of cellulose to furans and small oxygenates, Energy Environ. Sci. 5 (2012), P.5414-5424. 